\title{
Water Management for Higher Potato Production: A Review
}

\section{Mahima Begum ${ }^{1}$, Mrinal Saikia ${ }^{2}$, Abhijit Sarmah ${ }^{2}$, Nayan Jyoti Ojah' Pompy Deka ${ }^{3}$, Poran Kishore Dutta ${ }^{4}$ and Ipsita Ojah ${ }^{5 *}$}

${ }^{1}$ Sugarcane Research Station, Buralikson, India

${ }^{2}$ Directorate of Research, ${ }^{3}$ Department of Agronomy, ${ }^{5}$ Department of Soil Science, Assam Agricultural University, Jorhat-13, India

${ }^{4}$ KVK (Kokrajhar), Assam Agricultural University, India

*Corresponding author

\begin{tabular}{|c|c|}
\hline & A B S T R A C T \\
\hline Keywords & \multirow{5}{*}{$\begin{array}{l}\text { The potato is a winter season crop which requires sufficient precipitation during } \\
\text { the later crop growth stages. It prefers a loamy textured soil for highest tuber yielc } \\
\text { due to its high storage capacity, good drainage and other favorable soi } \\
\text { characteristics. The potato is very specific in its moisture needs which are me } \\
\text { either from the reserve of conserved water in the soil or supplied through irrigation } \\
\text { or both. The shortage of water is usually one of the most important constraints for } \\
\text { higher yield and lack of adequate availability of water can adversely affect the } \\
\text { yield and quality of the crop. Control of soil moisture as an important factor in } \\
\text { potato production because "potato plants require a high degree of soil aeration" or } \\
\text { because "even temporary dryness" may reduce yield. Therefore, proper study is } \\
\text { required to carry out the best water management practices for better water use } \\
\text { efficiencv and vield of potato. }\end{array}$} \\
\hline $\begin{array}{l}\text { Potato, Deficit Irrigation, } \\
\text { Water management, } \\
\text { Water scarcity }\end{array}$ & \\
\hline Article Info & \\
\hline $\begin{array}{l}\text { Accepted: } \\
\text { 04 April } 2018 \\
\text { Available Online: } \\
10 \text { May } 2018\end{array}$ & \\
\hline & \\
\hline
\end{tabular}

\section{Introduction}

Potato after wheat, rice and corn accounted for the fourth position and the number of producing countries is in the second after the corn. Potato biodiversity is enormous. Nearly 5000 varieties of potatoes have been detected. Potato is basically a temperate crop, but it is grown in various climates from the tropic to sub-polar and comprises a major food crop in many countries (Wright and Stack, 1990). Water has a special significance in the potato production as the plant has sparse and shallow root system (Sood and Sharma, 1993).

\section{Need for water management}

The need for readily available moisture is that potato is a short duration crop, which produces large foliage rapidly, readily available moisture is, therefore essential for maintaining leaves in turgid condition and for tuber enlargement stomata should remain open throughout the day to enable the crop to 
maintain high photosynthesis rate. Again, since the plant has sparse and shallow root system, 70 per cent of total water need is met by the crop from the upper $30 \mathrm{~cm}$ layer (Singh, 1968) as the stolons and tuber roots can draw water under less moisture condition whereas basal and functional roots do not transport water to the tuber although the plant posses different types of roots i.e. those originating at main stem (basal roots), roots arising from the main stem at the stolon function (function roots), roots on stolons (stolons roots) and roots arises from tuber bud bases (tuber roots) (Patta and Kratzke 1985). Several studies have confirmed the water requirement of the crop differently. The water requirement of potato varies from 350-550 $\mathrm{mm}$ depending upon the length of growing season, atmospheric demand, soil type, crop variety, etc. (Sood and Sharma, 1993). On the other hand, Sharma (1988) reported that plant needs $500-600 \mathrm{~mm}$ of water throughout its life cycle, as the plant is very susceptible or sensitive to water stress compared to many other crops (King and Stark, 1997). Plant experiencing water stress condition during the crop growth period shows different symptoms, such as reduced leaf size, fewer leaves, reduced plant height compared to plant grown in non-stressed condition (Hang and Miller, 1986) and finally yield is reduced due to water stress (Vanloon, 1981). But the extent to which yield is reduced depends largely on the stage of development at which plant suffers from stress. If the moisture stress prevails at tuber initiation stage, the yield loss is greater $(31 \%)$ than at tuber development stage $(21 \%)$, this is due to greater reduction in photosynthesis $(40 \%)$ and leaf area $(35 \%)$ at tuber initiation stage than at tuber development stage (Kumar and Minhas, 1994). It has been also reported that water shortage during tuber bulking stage decreased yield to a greater extent than during other growth stage i.e. tuber initiation as during bulking a gradual increase in water stress decreased yield and increased small size tubers (Miller and Martin, 1987). If the plant undergoes water deficit during later part of crop life cycle it reduces the yield but larger potatoes were obtained and plant usually produces small size potatoes if the plant experiences water deficit during early growth period indicating early growth period more susceptible to water stress and water plays an important role on tuber size distribution. Water stress during early tuber formation and bulking causes external tuber defects which lead to loss of grade (Salter and Goode, 1967; Thompson and Kelly, 1957).

\section{Irrigation scheduling}

Irrigation scheduling is one of the most important tools for developing best management practices for irrigated areas (Kiziloglu et al., 2006). If shortage of readily available water in the soil is eliminated by irrigation it is possible to achieve high and stable yields of potatoes, at the level of 40-50 $\mathrm{t} \mathrm{ha}^{-1}$ or higher. Potato plant, like most vegetable crops requires frequent and light irrigation at low soil moisture content (0.2-0.3 bar) (Singh and Grewal, 1979). Milić et al., 2010 found out that the lower limit of optimum soil moisture for potatoes is $70 \%$ of field water capacity (FWC) when this crop is grown in a soil with medium texture. Whereas, Costa et al., 1997, claimed that the lower limit of optimum soil moisture for potatoes is reached when $50 \%$ of available water is consumed.

The potato growing season in plains coincide with period of high rates of evaporation, especially before vegetative growth develops and covers the soil surface completely by growing canopy. Therefore, a preliminary step to a more intensive exploitation of the available agroecological conditions or to the development of irrigation schedules for any crop implies a study of crop requirements for 
water, that is, the evapotranspiration (ET) for any particular crop. To fully utilize the genetic yield potentials of potato, to achieve high and stable yields, it is necessary to gain knowledge of the crop's capabilities under conditions of dry farming and irrigation.

The current water scarcity, primarily in the arid regions, has forced farmers to extensively explore the possibility of including saline water in the irrigation regimes of agricultural crops. Whereas, if management is not practiced properly, application of irrigation water with low/poor quality water may compound existing problems of field with soil salinity (Nagaz et al., 2017). It is well established that, applying saline water continuously for irrigation might result in salt accumulation close to the soil surface (Oron et al., 1995).

The problems mentioned above can be overcome by applying saline water through a drip- irrigation system. It is anticipated that under drip irrigation, the salt front is partially driven down into the deeper soil bulk media and to the periphery of the root zone, thus minimizing the risk of damaging the main roots of the plants. Moreover, the improved moisture conditions in the vicinity of the emitter offset the inhibiting effects of the presence of the salts in the saline water (Michelakis et al., 1993). Additionally, it can result in water saving if the correct management procedures are applied. To further address the issue of water shortage and soil salinization, new irrigation scheduling techniques such as deficit irrigation (DI), which are not necessarily based on full crop water requirement can be investigated.

Deficit irrigation, widely reported as a valuable strategy for dry regions (Fereres and Soriano, 2007), is particularly important for crops which are frequently subject to chronic water shortages. Due to chronic water shortage and soil degradation hazards in irrigated areas, there is a need to develop strategies that may help to save water and control salinity.

In the absence of drainage systems and under conditions of high evaporative demand and chronic shortages of water, techniques based on irrigation restrictions during the whole growing period without substantially affecting yields seem to be reasonably appropriate. One consequence of reducing irrigation water use by Deficit irrigation practice (DI) is the greater risk of increased soil salinity due to reduced leaching, and its impact on the sustainability of the irrigation (Schoups et al., 2005). The evaluation of soil salinity developed under drip irrigation with DI practice should be investigated. Therefore, various deficit irrigation strategies have been applied to pearl millet and potato crops considered as moderately tolerant and relatively sensitive to water stress caused by deficit irrigation or salinity (Maas and Hoffman, 1977).

Moreover, with rising cost of pumping of irrigation water, low commodity prices, inadequate irrigation system capacities and limited irrigation water supplies are reason for which many irrigators deliberately use less water than required for maximum yield (Cracium and Cracium, 1999). Deficit irrigation is a strategy which allows crops to sustain some degree of water deficit to irrigation cost and potentially increase revenue. The goal of deficit irrigation is to enhance the economic returns with limited use of water and energy. However, deficit irrigation may be difficult to manage because of reduction in tuber yield and quality can results even for brief period of water stress following tuber set (Eldredge et al., 1992; Shock et al., 1993; Wright and Stank, 1990). On the other hand, Cappaert et al., 1994, stated that potato is tolerant to water stress before tuber formation period. 
Under deficit irrigation, about 50 per cent less irrigation water was required under drip irrigation system (Aggarwal et al., 1973; Sood and Singh, 1989). Deficit irrigation can lead to increased profit where water costs are high or where water supplies are limited.

\section{Irrigation methods}

Generally furrow method of irrigation is recommended for potato. However, upto 38 per cent irrigation water could be saved by applying water in alternates furrows irrigation turn at the expenses of 10.7 per cent decrease in yield (Bhan and Dharma 1982).

This practice seems promising where irrigation water is a major limiting factor in potato production. Also in the areas of undulating topography, as in hills and scarce water supply condition, where other methods of irrigation could not be adopted, sprinkler irrigation is applied which is expected to economise in water by about 40 per cent (Singh et al., 1983). Trickle and sprinkler irrigation system, respectively achieve water saving upto 50 and $30 \%$ compared with surface irrigation (Jamal et al., 2001).

In some cases trickle or surface irrigation is better than sprinkler irrigation as any moisture on the leaves increases the potential of leaf disease. In small holdings using irrigation gated pipes and double planting row bed, partially wetted furrow irrigation achieves water saving as trickle irrigation, furthermore, it decreases installation cost compared with other system (Amer, 2009). Drip irrigation system also offers a huge potential to farmers to grow more food with limited water supplies.

\section{Critical stages and potato yield}

The planning of irrigation must take into account three phases of the development of the potato plant, each one of which influences yield. Hence the crop should have adequate moisture at all these three stages. The first phase of stolon formation, second phase of tuber formation and third phase of tuber development are most critical from the moisture availability point of view. These are the decisive period for single tuber weight. A period of interrupted growth, through drought, during this phase may result in the production of undersized and malformed tubers. Thus a regular supply of moisture from the beginning of stolon formation to maturity should be ensured (Steineck, 1958). Many experimental result stated that water stress at the early two stages i.e. stolonization and tuberization showed sharp negative response to the yield of potato compared with bulking and tuber enlargement stages Hassan et al., (2002).

Therefore, the knowledge of critical stages of water stress is essential for judicious use of irrigation water specially when supply of irrigation water is limited, irrigation strategy may be based on avoiding soil moisture stress during the period of stolonization, tuber initiation, yield formation by restricting the water supply during early vegetative and later part of growth period (Doorenbos and Kassam, 1979).

Pre-planting moisture is also important for optimum growth and yield of potato (Grewal et al., 1990). They considered pre-emergence, stolonization, stage, tuberization and bulking stage as critical stages for potato.

This study further revealed that soil moisture retention capacity, stage of crop growth, atmospheric factor and rooting pattern of cultivar are important and irrigation scheduling should be based upon those factors.

If the optimum moisture is maintained during the critical stages and sub-optimal condition 
during other stages, then it saved about 30 per cent irrigation water without significant yield reduction. This practice also increased the water use efficiency (WUE) and could be advocated for areas with limited water supply (Singh and Grewal, 1979). However, maintaining minimum water stress during critical stages of crop growth such as early vegetative, tuber initiation and tuber bulking stage, the crop could be saved from significant yield reduction (Iqbal et al., 1999). Potato should be irrigated at 0.3 bar tension or at $15-20 \mathrm{~mm}$ CPE during the critical stages (Hukkeri et al., 1982). However, timing of water stress influenced the tuber yield; the stress imposed at later growth stage has least reduction in yield, whereas that imposed at early development caused the greatest yield reduction followed by tuber formation stage. The growth stage that is most sensitive to water stress is most responsible to irrigation as compared to tuber formation and flowering. It was also reported that applying deficit irrigation at appropriate growth stage could increase the efficiency of water use with non-adverse effect on yield (Iqbal et al., 1999).

\section{Effect of irrigation water on tuber yield and quality}

Irrigation has a positive effect on tuber yield as well as quality and there is an increasing trend in tuber yield due to application of irrigation (Choudhuri et al., 1996). Tuber quality in terms of shape and size alters due to irrigation practice in potato.

Among the different irrigation methods, sprinkler and drip irrigation significantly increased the tuber yield to the extent of 93.5 per cent and 21.2 per cent, respectively compared to furrow irrigation method (Raskar, 2003). However, both yield and tuber grade responds linearly to applied water. Drip irrigation is most efficient technique of irrigation which supplies the requisite soil moisture to raise a crop successfully even in sandy soil and under water stress condition resulting in higher water use-efficiency due to increased available soil moisture and reduced water loss. The method also modifies the soil and maintains the proper moisture condition (Singh et al., 1973).

In arid region, studies have shown that potato yield responded linearly to applied water where irrigation plus rainfall is less than or equal to evapo-transpiration (ETo) (Hane and Pumphery, 1984; Hegney and Hoffman, 1997).

Potato yield and grade diminishes by relatively mild water stress (Epstein and Grant, 1973). They also reported that a potato plant begins to experience water stress when soil water tension exceeds $20 \mathrm{kPa}$. Potato tuber grade as determined by shape, smoothness, free from visible defects such as growth cracks, bumbells and knobs is highly sensitive to irrigation deficiencies (Robins and Domingo, 1956; Vanloon, 1981).

Water stress during early tuber bulking reduces specific gravity and increases reducing sugar associated with dark end and fry colour. Dark ends may become more severe after tubers have been stored (Eldrege et al., 1996). Water stress before tuber initiation has no deleterious effect on tuber quality (Shock et al., 1992) while stress later during tuber bulking can cause dark stem end, fry colour and reduced the specific gravity (Eldredge et al., 1992, 1996).

Water stress or wide variation in soil moisture content (SMC) has been associated with (1) secondary growth (2) growth cracks (3) other tuber malformation, including physiological disorders such as brown centre, hollow-heart, translucent end (4) bruise susceptibility and heat stress (Eldredge et al., 1992, 1996; Hiller et al., 1985). 
But well-watered potato plant subjected to irrigation deficit after tuber initiation during middle of the growing season produced tubers with reduced specific gravity (Hang and Miller, 1986; Miller and Martin, 1987b).

Increase in frequency of irrigation from 6 to 8 decreased the specific gravity, dry matter as well as ascorbic acid content of tubers but the effect on protein content was non-significant (Singh et al., 1984). The specific gravity of Russet Burbank reduced following deficit irrigation at 80 per cent ET on a sandy soil (Miller and Martin 1987). Whereas, starch content decreased from 19.7 to 16.1 per cent when the available soil moisture was increased from 60 to 80 per cent (Narang and Kanwal, 1997)

\section{Potato and water use efficiency}

Water-use-efficiency of potato crop varied between 5.4 to $12 \mathrm{~kg} / \mathrm{m}^{3}$ with respect to irrigation, programme regime, amount of fertilizer and production technique (Wright and Stark, 1990). The water use efficiency for irrigated potato crops in humid and subtropics areas lies between 4-7 kg/m (Dorenbos and Kassam, 1979).

Potato is grown under assured irrigation conditions in the plains during rabi season (October-November), where irrigation is applied through furrow method. But, the water use efficiency (WUE) of furrow method seldom exceeds 50 per cent (Sood and Sharma, 1993). To increase the irrigation water use efficiency further, the value of modern irrigation methods such as sprinkler and drip irrigation need to be accessed under different topographical conditions. Therefore various measures have been developed to improve water use efficiency. Drip irrigation in one of the most efficient method which gives high water use efficiency (WUE) as compared to furrow method. It ranged from
$6.3-8.6 \mathrm{~kg} / \mathrm{m}^{3}$ for drip irrigated potato (Yuan et al., 2003) as compared to furrow irrigated crop where water use efficiency was 4.54$4.66 \mathrm{~kg} / \mathrm{m}^{3}$ (Panigrahi et al., 2001). The water use efficiency for drip irrigated potato varies from $5.19-5.74 \mathrm{~kg} / \mathrm{m}^{3}$ as compared to furrow irrigated crop which ranged from 4.7-6.63 $\mathrm{kg} / \mathrm{m}^{3}$ under 30 per cent irrigation regime in both the irrigation system (Erdem et al., 2005).

In areas with high undulating topography and plateau zone, where soils are shallow and variable in depths are not amenable to leveling. In those areas furrow irrigation isn't possible. So, sprinkle system could be used in those areas. This system increased the crop yield by improving root and plant growth characters. The water use efficiency (WUE) was 4.63 and $2.65 \mathrm{q} / \mathrm{ha} / \mathrm{cm}$ under sprinkler and surface irrigation respectively (Singh et al., 1973). This system also economise on water by about 40 per cent (Sood and Singh, 1989).

When supply of irrigation water was limited, water use efficiency can be increased by avoiding soil moisture stress during the period of stolonization, tuber initiation, yield formation period by restricting the water supply during the early vegetative and later stage of crop growth (Doorenbos and Kassam, 1979; Salter and Goode, 1967). Water stress at later growth stress had little adverse effect; it is only water stress during stolonization and early tuberization, which could be regarded as critical stage for irrigation caused by considerable reduction in the number of tuber and yield (Hukkeri et al., 1975; Hukkeri, 1982). In this situation, water use efficiency could be increased by maintaining optimum soil moisture during the critical stages and sub-optimal condition during other growth stages resulted in saving of 30 per cent in irrigation without significant reduction in the yield. 


\section{Water use and fertilizer use efficiency}

Irrigation has direct role in modification of fertilizer use efficiency in case of potato cultivation. Better fertilizer use efficiency could be obtained with irrigation applied at appropriate stages (Chawla and Narda, 2003). They reported that $\mathrm{No}_{3}{ }^{-}-\mathrm{N}$ concentration in furrow irrigated crop increased in the top layer after first irrigation and decreased with depth thereafter, while after second irrigation, the peak of $\mathrm{No}_{3}{ }^{-}-\mathrm{N}$ shifted to deeper layer. In trickle fertigated crop, the maximum concentration of $\mathrm{No}_{3}{ }^{-}-\mathrm{N}$ remained confined to $30-60 \mathrm{~cm}$ soil depth, the soil $\mathrm{No}_{3}{ }^{-}-\mathrm{N}$ concentration also increased with high irrigation level at the depth of $90-180$ or 200 cm (Stark, 1993; Halitligil et al., 2002).

The increased level of irrigation also resulted in losses of $\mathrm{N}$ with increasing rate under sprinkler and trickle method. In sprinkler irrigation $\mathrm{N}$ losses varied between 15 per cent and 78 per cent, whereas, under trickle irrigation it varied between 41 per cent and 71 per cent (Halitligil et al., 2002). In free flooding conditions also significant quantity of urea moved along with the wetting front in an unhydrolysed form to give a peak of $\mathrm{No}^{-3} \mathrm{~N}$ in the surface soil profile (Beri et al., 1978).

The nitrogen use-efficiency of potato crop decreases with the increase in water level, where the value ranged from 472 to $33 \mathrm{~g} \mathrm{~kg}^{-1}$ for sprinkler irrigation and 344 to $16 \mathrm{gm} \mathrm{kg}^{-1}$ for trickle/drip irrigation which was less than data given by Meyor and Marcum (1998).

The moisture need of potato vary depending upon the time and place. When supply of irrigation water was limited, water use efficiency can be increased by avoiding soil moisture stress during the period of stolonization, tuber initiation, and yield. Deficient irrigation is one of strategy under scared water condition. Applying saline water continuously for irrigation might result in salt accumulation close to the soil surface which can be avoided by adopting drip irrigation system. Improve irrigation practices based on timing and amount plays a crucial role on potato production.

Scientific study on effective water use efficiency with regard to depletion of irrigation water under prevailing climatic condition is necessary. Therefore more efficient water management with proper irrigation method is critical for optimizing for crop production and maximization of return yield.

Accordingly improved irrigation technique using conservation agriculture approached. Use no-til and soil cover practices should be followed to reduced soil evaporation under arid and semi-arid condition and some government policy must be developed to support farmer to adopt drip irrigation in case of use of saline water.

\section{References}

Aggarwal, M.C., Dixit, S.P. and Singh, K. (1973). Studies on drip method of irrigation for potato. Indian J. Hort. 30: 418-420.

AI-Jamal, M.S., Ball, S., Samims, T.W., (2001). Comparison of Sprinkler, trickle and furrow irrigation efficiencies for more onion production. Agric. Water Manage, 46(3): 253-266

Amer, K.H. (2009). The possibilty of improving surface irrigation with blocked end in sparse grape trees. Misr, J. Agri. Eng 26(2): 836-862

Beri, V., Bran, S.S., Sekhon, G.S. and Ghuman, B.S. (1978). Extent of urea leaching in soils and its bio-chemical control. J. Ind. Soc. Soil. Sci. 26: 116-124.

Bhan, S. and Dharma, C.S. (1982). Effect of frequency and method of irrigation on potato. Indian J. Agron. 27: 227-30. 
Cappaert, M.R., Powelson, M.L., Chizstensen, N.W., Stevenson, W.R. and Rouse, D.I. (1994). Assessment of irrigation as a method of managing potato early dying. Phytopathology 24: 792-800

Chawla, J.K. and Narda, N.K. (2003). Soil and plant $\mathrm{N}$ as influenced by furrow and trickle irrigation in potatoes. J. Indian Potato Assoc. 30(3-4): 285-290

Choudhuri, A.K., Saikia, M. and Deka, N.C. (1996) Effect of irrigation and nitrogen level on growth and tuber yield of potato Indian J. Soil Conserv 24(2): 147-149

Costa, L.D., Delle, V.G., Gianquintoi, G., Giovaanrdi R, Peressotti, A. (1997). Yield, water use efficiency and nitrogen uptake in potato: influence of drought stress, Potato Research: 40:19-34.

Cracium, I. and Cracium, M. and Naeseum (1999). Influence of irrigation on main crop yield under Rumanian plain condition. Vol. 36, Lucrari Stilntifice Agricultural University Lasl: 128-132.

Doorenbos, J. and Kassam, A.H. (1979). Yield response to water. Rome, FAO, p. 198 (Irrigation and Drainage paper, 3).

Eldredge, E.P., Holmes, Z.A., Mosley, A.R., Shock, C.C. and Stieber, T.D. (1996). Effect of transistory water stress on potato tuber stem-end reducing sugar and fry colour. Am. Potato J. 73: 517-530.

Eldredge, E.P., Shock, C.C. and Stieber, T.D. (1992). Plot sprinkler for irrigation research. Agron. J. 84: 1081-1984.

Erdem, T., Orta, A.H., Erdem, Y. And Okursoy, H. (2005). Crop water stress index under furrow and drip irrigation systems. Potato Res. 48(1-2): 49-58.

Epstein, E. and Grant, W.J. (1973). Water stress relations of the potato plant under field conditions. Agron. J. 65: 400-404.

Fereres E., Soriano M.A., (2007). Deficit irrigation for reducing agricultural water use. Journal of Experimental Botany, 58(2): 147-159.

Grewal, J.S., Sood, M.C. and Sharma, R.C. (1990). Water management in potato. Tech. Bull. No. 28, CPRI, Shimla.
Halitligil, M.B., Akin, A. and Ilbeyi, A. (2002). Nitrogen balance of nitrogen-15 applied as ammonium sulphate to irrigated potatoes in sandy textured soils. Biol. Fertil. Soils 35: 369-378.

Hane, D.C. and Pumphery, F.V. (1984). Yieldevaporation relationships and seasonal crop co-efficients for frequently irrigated potatoes. Am. Potato J. 61: 661-668.

Hang, A.N. and Miller, D.E. (1986). Yield and physiological responses of potatoes to deficit, high frequency sprinkler irrigation. Agron. J. 78: 436-440.

Hassan, A.A., Sarkar, A.A., Ali, H.M. and Karim, N. (2002). Effect of deficit irrigation at different growth stages on the yield of potato. Pakistan Journal of Biological Science 5(2): 128-134.

Hegney, M.A. and Hoffman, H.P. (1997). Potato irrigation development of irrigation scheduling guidelines. Hort. Res. and Dev. Corporation Project NP 6. Western Australia, Australia Department of Agriculture of Western Australia.

Hiller, L.K., Koller, D.C. and Thorton, R.E. (1985). Physiological disorder of potato tubers. In potato Physiology. P.H. Li (ed.), pp. 389-455.

Hukkeri, S.B. (1982). Irrigation scheduling for higher water-use-efficiency in potato production. Potato in Developing Countries (B.B. Nagaich et al., Eds.). Indian Potato Assoc. Pp. 163-171.

Hukkeri, S.B., Sharma, A.K., Nimbole, N.N. and Basantani, H.T. (1975). Studies on stress day index for timing of irrigation to potato. Indian J. Agric. Sci. 40: 318-325.

Iqbal, M.M., Shah, S.M., Mohamad, W. and Nazaz, H. (1999). Field response of potato subjected to water stress at different growth stages. Crop yield response to deficit irrigation, Khuwer Academic Publishers, The Netherland, pp. 213-223.

Jamal, A., Ball. M.S, Samims, T.W., (2001). Comparison of Sprinkler, trickle and furrow irrigation efficiencies for more onion production. Agric. Water Manage, 46(3): 253-266. 
Kamel, N., Fathia, E. M., Mohamed, M. Masmoudi., Netij, B. M., (2017). Soil Salinity under deficit drip irrigation of potato and millet in an arid environment JAEID 2017, 111 (1): 207-223.

King, B.A. and Stark, J.C. (1997). Potato irrigation management. Bull 789, Cooperative Extension system. College of Agricultural Idaho, University of Idaho, pp. 16.

Kiziloglu, F.M., Sahin, U., Tunc, T., Diller, S. (2006). The effect of deficit irrigation on potato evapotranspiration and tuber under cool season and semiarid climatic conditions. Journal of Agronomy, 5(2): 284-288

Kumar, D. and Minhas, J.S. (1994). Effect of water stress on photosynthesis, productivity and water stress in potato. $J$. Indian Potato Assoc. 26(1-2): 5-10.

Maas E.V., Hoffman G.J., 1977. Crop salt tolerance: Current assessment. J. Irrig. Drain. Div. Am. Soc. Civ. Eng., 103, 115 134.

Meyer, R.D. and Marcum, D.B. (1998). Potato yield, petiole nitrogen and soil nitrogen response to water and nitrogen. Agron. J. 90: 420-429.

Michelakis N., Vougioukalou E., Clapaki G., 1993. Water use, wetted soil volume, root distribution and yield of avocado under drip irrigation. Agric. Water Manage. 24, 119-131.

Milic, S., Bosnjak, D.J., Maksimovic, L., PejIic, B., Sekulic, P., Ninkov, J., ZeremskiŠkoroc, T. (2010). Potato yield and yield structure depending on irrigation. Field and Vegetable Crops Research, 47(1): 251-265.

Miller, D.E. and Martin, M.W. (1987). The effect of irrigation regime and sub soiling on yield and quality of three potato cultivars. Am. Potato J. 64: 17-26.

Miller, D.E. and Martin, M.W. (1987b). Effect of declining of interrupted irrigation on yield and quality of three potato cultivars grown on sandy soil. Am. Potato J. 64: 109-118.
Nagaz, K., Mokh, E.F., Masmoudi, M., Mechila, N (2017). Soil salinity under deficiet irrigation of potato and millet in arid enviroment. J. Agriculture and Environment for International Development, 111(1): 207-223

Narang, R.S. and Kanwal, S.S. (1997). Effect of various soil moisture regimes, different levels of nitrogen and different spacing on the qualities of potato tubers. J. Res. (PAU) 8: 432-436.

Oron G., DeMalach Y., Gillerman L., David I., (1995). Pear response to saline water application under subsurface drip irrigation, proceedings of the $5^{\text {th }}$ International microirrigation Congress, Orlando, FL, 2-6 April, pp. 97-103.

Panigrahi, B., Panda, B.N. and Raghuwansi, N.S. (2001). Potato water use and yield under furrow irrigation. Irrig. Sci. 20: 155-163.

Patta, M.G. and Kratzke, J.P. (1985). Evidence for the existence of functional roots on potato tubers and stolons significance in water transport to the tuber. American Potato Journal 62(5): 227-236.

Raskar, B.S. (2003). Increasing yield potential of potato by using irrigation and fertilizer level. Indian J. Agron. 48(3): 229-231.

Robin, J.S. and Domingo, C.E. (1956). Potato yield and tuber shape as affected by severe soil moisture deficits and plant spacing. Agron. J. 48: 488-492.

Salter, P.J. and Goode, J.E. (1967). Crop responses to water at different stages of growth, Farnham Royal. The United Kingdom, Common Wealth Agricultural Bureau.

Schoups G., Hopmans J.W., Young C.A., Vrugt J.A., Wallender W.W., Tanji K.K., Panday S., (2005). Sustainability of irrigated agriculture in the San Joaquin alley, California. In: Proc National Academy of Sciences USA 102, pp. 15352-15356.

Sharma, R.C. (1988). Pre-planting soaking treatment of seed tubers for increasing yield of potato (Solanum tuberosum L.). Indian J. Agric. Sci. 58: 315-316. 
Shock, C.C., Holmes, Z.A., Steiber, T.D., Eldredge, E.P. and Zhang, P. (1993). The effect of timed water stress on quality, total solids and reducing sugar content of potatoes. Am. Potato J. 70: 227-241.

Singh, A.K. (1968). Water requirement of potatoes. Proc. Symp. Water Management, Udaipur, 169-172

Singh, B., Khera, K.L. and Sandhu, B.S. (1983). Response of autumn potato to method of irrigation application and planting. Indian J. Ecol. 10: 157-160.

Singh, B.N. and Grewal, J.S. (1979). Effect of soil moisture stress on different growth stages on the yield of potato variety $\mathrm{K}$ Chandramukhi. J. Indian Potato Assoc. 6: 1347-139.

Singh, K., Kumar, V. And Pandita, M.L. (1973). Influence of sprinkler and surface irrigation under different levels of nitrogen on the growth, yield and quality of potato. Haryana, J. Hort. Sci. 101-111.

Singh, S., Shukla, D.N. and Mishra, H.P. (1984). Effect of phosphorus and irrigation treatments on the nutritive and cooking qualities of potato tubers. Prog. Hort. 16: 109-112.

Sood, M. and Sharma (1993). Water optimization and requirement. Advances in Horticulture. Chanda, K.L. and Grewal, J.S. (Eds.). Malhotra Publishing House. New Delhi -64,

Sood, M.C. and Singh, N. (1989). Water optimization and requirement of potato crop. Annual Scientific Report CPRI Shimla (1981).

Stark, J.C., McCann, I.R., Westermann, D.T., Izadi, B. and Tindal, T.A. (1993). Potato response to split nitrogen timing with varying amounts of excessive irrigation. Am. Potato J. 70: 65-77.

Steineck, O. (1958). Die Bewassarung der kartoffel. (Irrigation of the potato). Dtsch. Landw. Pr. 81 N. 19, 185-6. Illus. (Hocksch F. Bodenbultuv, Vienna Field Crop). Abstract. 12(1): 1959.

Thompson, H.C. and Kelley, W.C. (1957). Vegetable crops, New York, USA, McGraw Hill, Inc 253-266

Vanloon, C.D. (1981). The effect of water stress on potato growth, development and yield. American Potato Journal 55: 51-69.

Wright, J.L. and Stark, J.C. (1990). Potato. In: Stewart, B.A., Neilsen, D.R. (Eds.): Irrigation of Agricultural Crops, ASACSSA-SSSA. Pub., Agron, Monog. No. 31, WI, pp. 859-888.

Wu. I.P., Gitlin, H.M., (1975). Irrigation efficiencies of surface, sprinkler and drip irrigation. Reprinted from proceedings Second World Congress, International Water Resources Association, New Delhi, December, 1975 vol (1): 191-199.

Yuan, B.Z., Nishiyama, S. and Kang, Y. (2003). Effects of different irrigation regimes on the growth and yield of drip irrigated potato. Agric. Water Manage. 63: 157167.

\section{How to cite this article:}

Mahima Begum, Mrinal Saikia, Abhijit Sarmah, Nayan Jyoti Ojah, Pompy Deka, Poran Kishore Dutta and Ipsita Ojah. 2018. Water Management for Higher Potato Production: A Review. Int.J.Curr.Microbiol.App.Sci. 7(05): 24-33.

doi: https://doi.org/10.20546/ijcmas.2018.705.004 